Proc. Estonian Acad. Sci. Geol., 2006, 55, 2, 156-174

\title{
Lower Ordovician Leetse Formation in the North Estonian Klint area
}

\author{
Viive Viira, Kaisa Mens, and Jüri Nemliher \\ Institute of Geology at Tallinn University of Technology, Estonia pst. 7, 10143 Tallinn, Estonia; \\ viira@gi.ee,nemliher@gi.ee
}

Received 27 December 2005, in revised form 8 February 2006

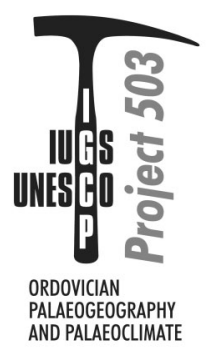

\begin{abstract}
Sequences of the Leetse Formation were studied in order to find out the conodont biozonation, grain-size distribution, and glauconite mineral properties and their variations along the North Estonian Klint. On the basis of the conodont zonation of the Saka section, combined with earlier data, it was found that the Leetse Formation belongs to the Paroistodus proteus, Prioniodus elegans, and Oepikodus evae zones of various thickness and completeness along the North Estonian Klint. The Pr. elegans Zone of the Saka section was found to be remarkably complete and correlate well with equivalent intervals of sections in the St. Petersburg Region. Poorly lithified glauconitic sandstones of the Leetse Formation vary lithologically vertically as well as laterally. The Leetse Formation in the west has been repeatedly redeposited and is depleted in suspended fraction, while in the east it is more homogeneous and represents continuous shallow-water conditions. Glauconite is represented by a potassiumrich variety (about $9 \% \mathrm{~K}_{2} \mathrm{O}$ ) and most likely forms at least two discrete modifications. Laterally, glauconite of the Leetse Formation in the western part of the klint contains less $\mathrm{K}$ than that of the eastern part, indicating faster sedimentation. The $d_{(001)}$ value of glauconite diminishes upwards in
\end{abstract} the sequence, indicating acceleration of the sedimentation rate.

Key words: Leetse Formation, conodont biozonation, grain-size data, glauconite mineralogy, Ordovician, Estonia.

\section{INTRODUCTION}

The Lower Ordovician Leetse Formation is a glauconite-rich sandy rock body, easily distinguishable in sections along the entire North Estonian Klint and adjacent area, stratigraphically related to the Hunneberg and Billingen regional stages. In the main part, the rocks of the Leetse Formation are represented by loose glauconitic silt- and sandstones, resting on the claystones of the Varangu Formation, or (with a hiatus) directly on the graptolite argillites (black shale) of the Türisalu Formation, and overlain by glauconitic carbonate rocks of the Toila 
Formation. The Leetse Formation varies in thickness and its sandy lower part grades upwards into quartzose glauconite limestone of the younger Mäeküla Member (see Meidla 1997 for stratigraphic details).

The variability in the thickness, grain-size distribution, and glauconite content of the Leetse Formation has been studied for years (Kleesment \& Mägi 1975; Mägi 1970, 1984). Based on the ratio of glauconite to siliciclastic grains in the sequence, the Klooga and Joa members have been distinguished in the Leetse Formation (Mägi 1970).

Besides the characteristic glauconite content, the Leetse Formation is known as the strata where the first conodonts were described, from the same beds in the St. Petersburg region (Pander 1856). Conodonts of the North Estonian Leetse Formation have been studied for different purposes during a long period (Öpik 1936; Viira 1966, 1974; Mägi \& Viira 1976; Mägi 1984; Mägi et al. 1989; Viira et al. 2001; Löfgren et al. 2005).

Glauconite is a characteristic admixture of the sediments of the Leetse Formation. Generally, the presence of glauconite is attributed to a low sedimentation rate, while the properties of this mineral are reported to reflect the sedimentation character and speed (Odin 1988).

The present study deals with lateral changes along the North Estonian Klint area, including conodont biozonation, grain size data, and glauconite mineralogy. The aim of the study is to estimate the concurrent changes in order to clarify the character of sedimentation and its vertical and lateral variations during Hunneberg and Billingen time.

\section{MATERIAL AND METHODS}

Conodont data for this paper have been obtained from eight previously studied sections (see references above) and the recently studied Saka section (Fig. 1). The collections of conodonts are deposited in the Institute of Geology at Tallinn University of Technology. The illustrated specimens bear the collection number GIT-495.

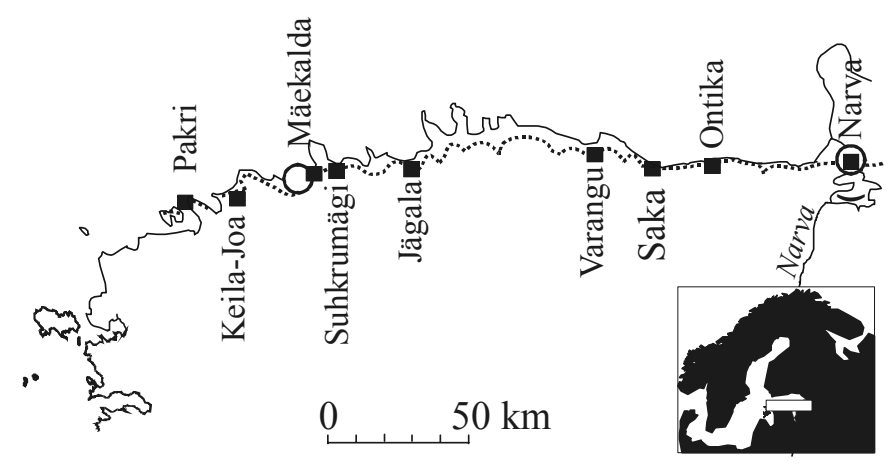

Fig. 1. Location of the studied sections on the North Estonian Klint. 
The western Pakri Cape (21 samples) (see also Löfgren et al. 2005) and eastern Saka (16 samples) sections were subjected to grain-size analysis and studies of the glauconite mineralogy. Mostly unconsolidated siliciclastic deposits of the Leetse Formation vary from sand- to claystones and thus supplementary preparation for grain-size analysis was not needed. However, as the samples contained mosaic or spotty carbonate cement, they were treated with $10 \%$ acetic acid solution.

We applied standard sieve analysis: $100 \mathrm{~g}$ of rock material was weighed, the clay fraction $(<0.002 \mathrm{~mm})$ was washed out using distilled water, samples were dried and sieved out on dry state conditions on a set of $0.5,0.25,0.1$, and $0.05 \mathrm{~mm}$ sieves. The coarse, medium, fine, and very fine sand and silt fractions were studied under a binocular microscope and the content of glauconite, siliciclastic grains, and bioclasts was estimated.

Glauconite mineralogy was studied using the XRD technique. From the $0.1-$ $0.05 \mathrm{~mm}$ sieved fraction (chosen because it contained less glauconite aggregates than pure glauconite grains) the study material was obtained by extra-strong magnetic field separation, mixed with TTY80 chlorite standard (13\%) and scanned within the range of 5 to $17^{\circ}$ of $2 \theta$ with a step of $0.05^{\circ}$. Fe-filtered Co radiation $\left(\lambda_{\mathrm{K} \alpha 1}=1.788965 \AA\right)$ was used; each point was measured during $5 \mathrm{~s}$. The background was removed by the sinusoidal formula; the diffraction angle was corrected linearly.

In order to estimate the homogeneity of element distribution in glauconite, 50 grains (samples Sa-04-4 and Pa-96-1) were studied by the SEM-EDX technology. Glauconite grains were extracted from the $0.1-0.25 \mathrm{~mm}$ fraction. The grains were embedded into epoxy resin and polished. The analyses were performed by the Jeol 840A SEM, operating on $20 \mathrm{KeV}$ level with the EDX Link AN10000 analyser using standard software.

\section{CONODONT BIOSTRATIGRAPHY}

\section{Conodonts of the Saka section}

Samples Sa-04-01 and Sa-04-02 represent the local basal bed of the Paroistodus proteus Zone, probably the Tripodus Subzone (Fig. 2). Paroistodus proteus (see Pl. I, figs 1-4, 6, 7) and Drepanodus arcuatus dominate in these samples. Conodonts from the underlying strata, Cordylodus angulatus and perhaps Paroistodus numarcuatus, are also present. These older conodonts together with many broken brownish-red specimens indicate intense redeposition in this interval.

The next sample, Sa-04-03, differs from previous ones by the presence of numerous almost complete light-coloured conodonts and few signs of redeposition. The fauna contains abundant $D$. arcuatus, and Par. proteus is rather numerous. Paltodus subaequalis and Acodus deltatus occur first in this sample. In the Par. proteus subzonation scheme of Löfgren (1994), A. deltatus was considered to be typical of the Oelandodus elongatus-Acodus deltatus Subzone, although in the reference section in Sjurberg, Sweden, it appears as low as the Tripodus Subzone. 


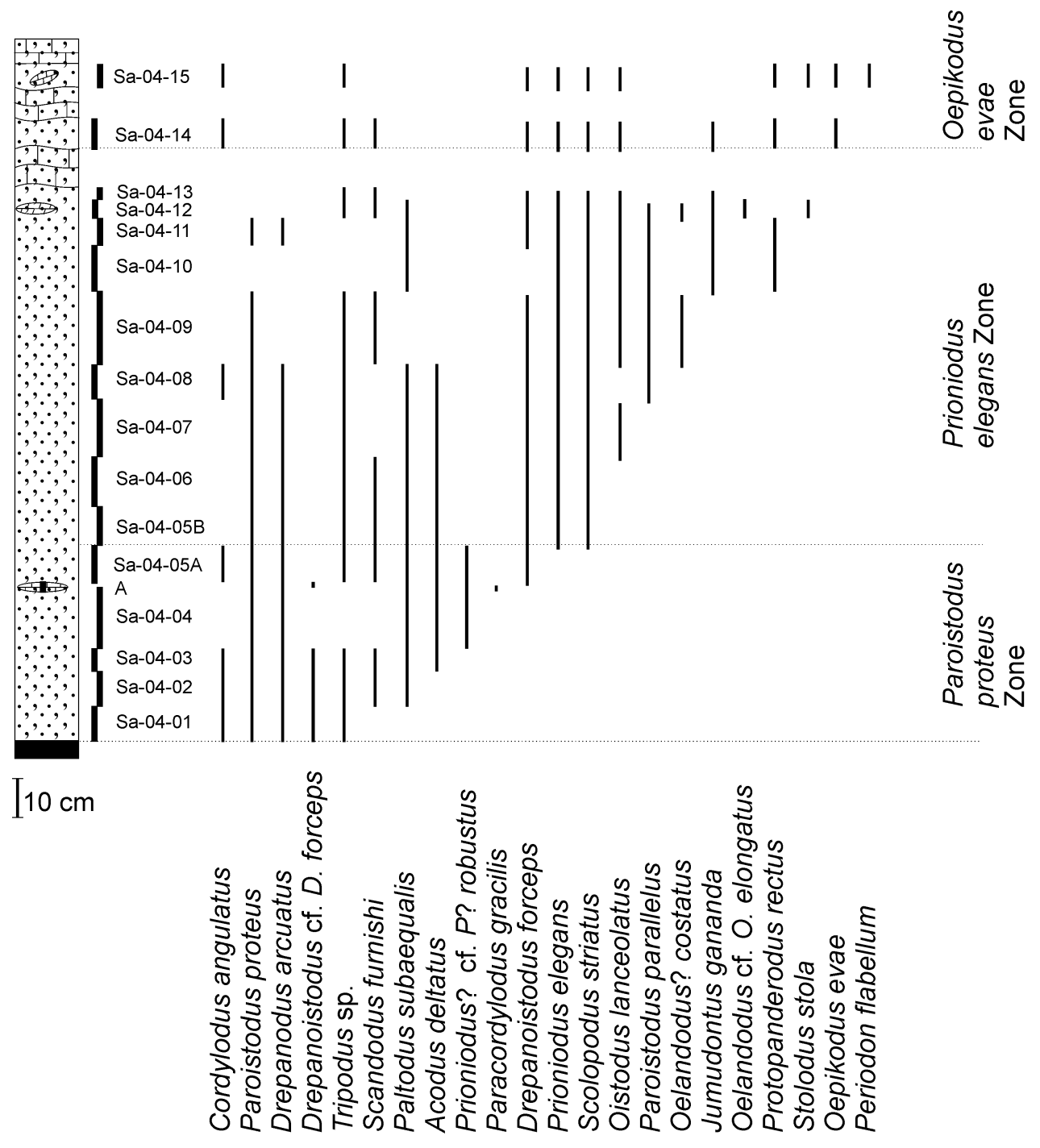

Fig. 2. Distribution of conodonts in the Saka section. For lithology see Fig. 3.

Samples Sa-04-04 and Sa-04-5A represent the interval of mixed light indigenous conodont elements and brownish redeposited specimens. The dominant species are Paltodus proteus, Acodus deltatus, also Drepanodus arcuatus, Paltodus subaequalis, and Scandodus furnishi. Drepanoistodus forceps replaces earlier $D$. cf. D. forceps in this interval. Sample A represents a calcareous nodule (Fig. 2) with the same fauna, except for a specimen of Paracordylodus gracilis (Pl. II, fig. 18), the index taxon of the $P$. gracilis Subzone. Some elements similar to Prioniodus? robustus (Pl. II, fig. 17) were identified in these three samples. 


\section{PLATE I}

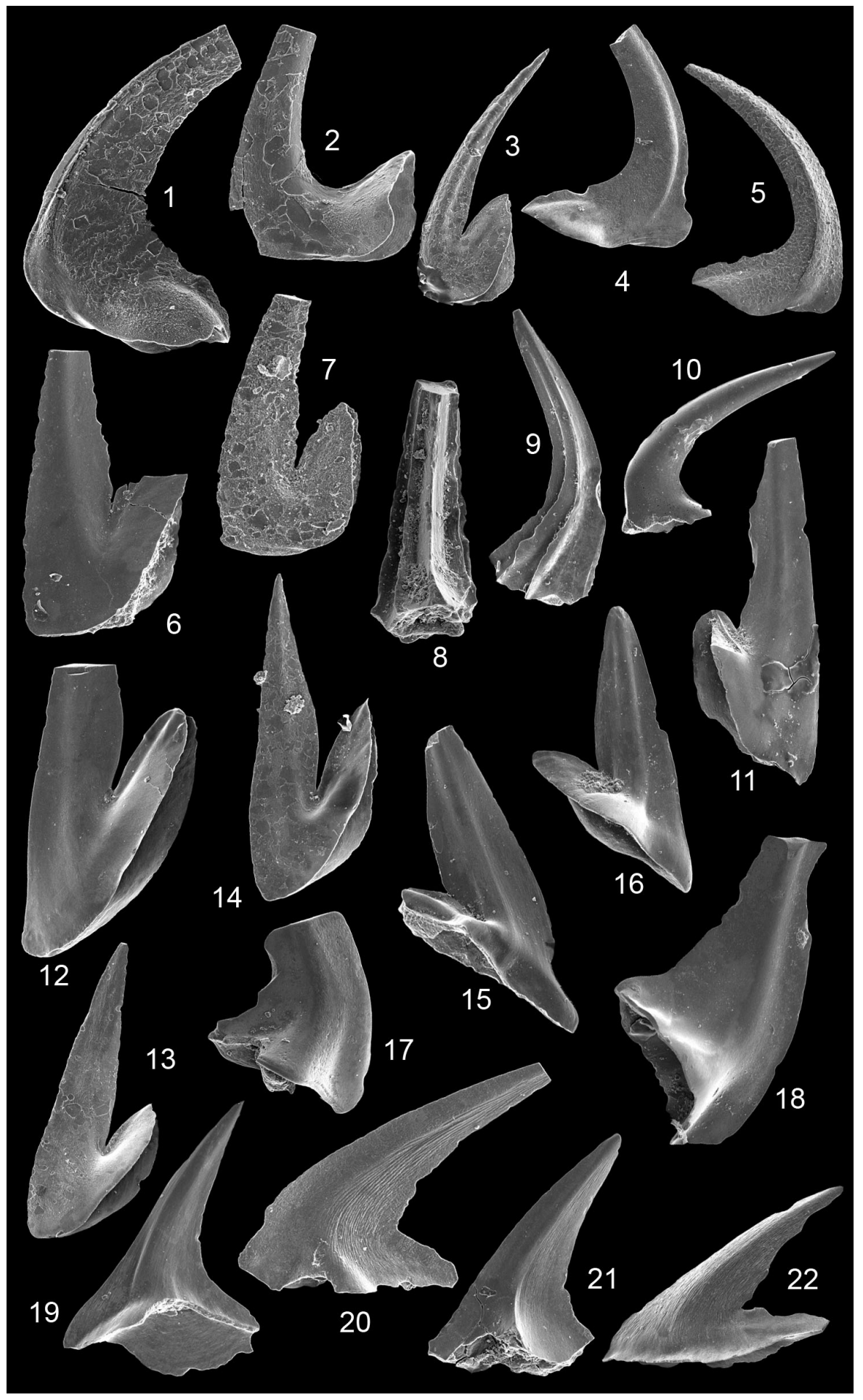


The index species Prioniodus elegans appears in sample Sa-04-5B. The Pr. elegans Zone ranges from this level up to sample Sa-04-13 (included) for about $1 \mathrm{~m}$ of the Leetse Formation. Gradual appearance of new species and a minimum number of redeposited conodonts characterize this interval in the Saka section, with successive appearance of the following species: Scolopodus striatus in Sa-04-5B, Oistodus lanceolatus in Sa-04-07, Paroistodus parallelus in Sa-04-08, Oelandodus? costatus in Sa-04-09, Jumudontus gananda and Protopanderodus rectus in Sa-04-10, and Stolodus stola in Sa-04-12. Some specimens similar to elements of Periodon primus occur in the three upper samples. It may be concluded that glauconitic sandstone representing the Pr. elegans Zone in the Saka section was deposited during a relatively long period and in quiet-water environment.

The two uppermost samples, Sa-04-14 and Sa-04-15, represent the Oepikodus evae Zone (Pl. III). The dominating species are Oistodus lanceolatus, Drepanoistodus forceps, and Scolopodus striatus. The zonal species O. evae is also quite numerous (Pl. III, figs 10,11). Periodon flabellum occurs in sample Sa-04-15.

Comparison of the conodonts of the Leetse Formation in the Saka section with those in the Pakri Cape section of western Estonia (Löfgren et al. 2005) shows a considerable difference in the zonation and redeposition of conodonts. In the Pakri Cape section the entire glauconitic sandstone unit of the Leetse Formation

\section{Explanation of Plate I}

Figs 1-4, 6, 7. Paroistodus proteus (Lindström). 1, 2, 4, P elements GIT 495-1, GIT 495-2, GIT 495-3; 3, 6, 7, M elements GIT 495-4, GIT 495-5, GIT 495-6. 1-4, sample A; 6, sample Sa-04-03; 7, sample Sa-04-02.

Fig. 5. Paroistodus parallelus (Pander). P element GIT 495-7; sample Sa-04-12.

Figs 8, 9. Tropodus? sp. 8, 9, S elements GIT 495-8, GIT 495-9. 8, sample Sa-04-01; 9, sample Sa-04-03.

Figs 10, 11. Scandodus furnishi Lindström. 10, S element GIT 495-10; 11, M element GIT 495-11. Sample Sa-04-02.

Figs 12-14. Drepanoistodus cf. D. forceps (Lindström). M elements GIT 495-12, GIT 495-13, GIT 495-14. 12, sample Sa-04-04; 13, 14, sample A.

Fig. 15. Tripodus sp. GIT 495-15, sample A.

Fig. 16. Paltodus subaequalis Pander. M element GIT 495-16; sample A.

Figs 17, 18. Acodus? sp. GIT 495-17, GIT 495-18. 17, sample Sa-04-04; 18, sample Sa-04-03.

Figs 19-22. Paltodus? sp. GIT 495-19 to GIT 495-22. 19, sample Sa-04-01; 20-22, sample Sa-04-04.

Fig. $1 \times 180$; figs $2,7,8,12,14,19,20 \times 150$; figs $3,6,21,22 \times 120$; figs 4, 9, 13, 15, $17 \times 90$; figs $5,11,16,18 \times 80$; fig. $10 \times 50$.

All conodonts from the Saka section. 
PLATE II
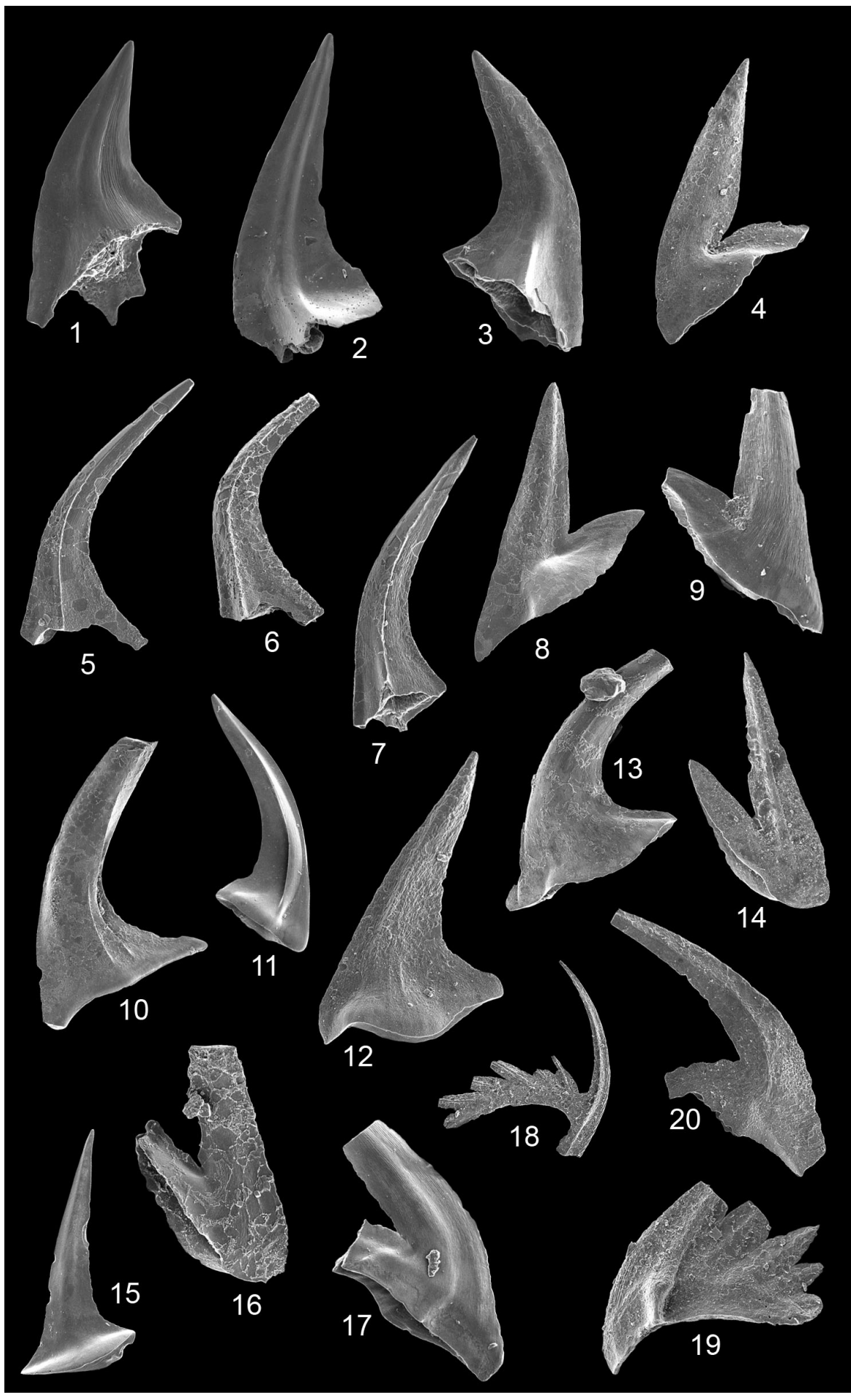
belongs to the Par. proteus Zone, whereas in Saka three quarters of this formation corresponds to the Pr. elegans Zone (Fig. 3). In the Pakri Cape section 58-97\% of conodont elements were redeposited, while conodonts were derived from several underlying strata (Löfgren et al. 2005). Older redeposited elements originated from below and beyond the investigated section, whereas younger redeposited elements come from the strata laterally corresponding to those in the studied section. Of older redeposited conodonts only few specimens of Cordylodus angulatus have been identified on some levels in the Saka section. The percentage of younger redeposited conodonts is small.

\section{Zonation of conodonts}

In addition to the Pakri Cape and Saka sections, conodonts of the Leetse Formation have earlier been studied in seven more sections in northern Estonia, unfortunately with much smaller sampling frequency (Fig. 3). Nevertheless, data from the westernmost Pakri Cape section to the easternmost Narva section show that in northern Estonia the glauconitic sandstone of the Leetse Formation accumulated at different times. So, in the Pakri Cape section almost the entire

\section{Explanation of Plate II}

Figs 1, 3-7. Acodus deltatus Lindstöm. 1, 3, P elements GIT 495-23, GIT 495-24; 4, M element GIT 495-25; 5-7, S elements GIT 495-26, GIT 495-27, GIT 495-28. 1, sample Sa-04-04; $3-7$, sample A.

Fig. 2. Tripodus sp. GIT 495-29. Sample Sa-04-09.

Figs 8-13. Paltodus subaequalis Pander. 8, 9, M elements GIT 495-30, GIT 495-31; 10, 11, 13, S elements GIT 495-32, GIT 495-33, GIT 495-34; 12, Sa element GIT 495-35. 8, 10, 12, 13, sample A; 9, sample Sa-04-02; 11, sample Sa-04-03.

Fig. 14. Drepanoistodus forceps (Lindström). M element GIT 495-36. Sample Sa-04-12.

Figs 15, 16. Drepanoistodus cf. D. forceps (Lindström). 15, Sa element GIT 495-37; 16, M element GIT 495-38. 15, sample Sa-04-04; 16, sample A.

Fig. 17. Prioniodus cf. P. robustus (Lindström). M element GIT 495-39. Sample Sa.04-04.

Fig. 18. Paracordylodus gracilis Lindström. S element GIT 495-40. Sample A.

Fig. 19. Fahraeusodus? sp. GIT 495-41. Sample Sa-04-12.

Fig. 20. Oelandodus cf. O. elongatus (Lindström). GIT 495-42. Sample Sa-04-12.

Fig. $1 \times 180$; figs $2,13,20 \times 80$; figs $3,5,9,12,19 \times 120$; figs $4,7,16,17 \times 150$; figs $6,8,14$, $15,18 \times 90$; figs $10,11 \times 60$.

All conodonts from the Saka section. 

formation has been ascribed to the Paroistodus proteus Zone with the Prioniodus elegans Zone in the gap and the uppermost calcareous part belonging to the Oepikodus evae Zone (Löfgren et al. 2005). A similar situation was reported for the Keila-Joa section (Mägi \& Viira 1976). Eastward of the Mäekalda section, the upper part of the Leetse Formation to a varying extent corresponds to the Pr. elegans Zone. Most of the formation represents the Pr. elegans Zone in the Saka section. The conodonts of the Pr. elegans Zone were identified in the St. Petersburg region, in the most complete sequence of this zone (Bergström 1988; Tolmacheva 2001; Tolmacheva et al. 2001). The uppermost part of the Leetse Formation belongs to the $O$. evae Zone in all studied sections.

The underlying rocks of the Varangu Formation (in places in gap) contain conodonts of the Paltodus deltifer Zone with two subzones in the Varangu section (Viira 1970; Viira et al. 1970).

The Par. proteus Zone in northern Estonian sections is represented by different combinations of subzones and extent, as compared to Swedish sections, where four subzones have been established (Löfgren 1993, 1994). In northern Estonian sections the lower, Drepanoistodus aff. D. amoneus Subzone is missing or reworked and mixed. Löfgren (1994) presumed that the index species is a predecessor of Drepanoistodus forceps. In the Saka section $D$. cf. D. forceps was identified (Pl. II), indicating the possible presence of a lower subzone. The second, Tripodus Subzone has been obliquely established in the Pakri Cape, Keila-Joa, Saka, Ontika, and probably some other sections, as many elements belonging to Tripodus have

\section{Explanation of Plate III}

Figs 1-8. Prioniodus elegans Pander. 1-3, 6, P elements GIT 495-43, GIT 495-44, GIT 495-45, GIT 495-46; 4, Sb element GIT 495-47; 5, 7, Sd element GIT 495-48, GIT 495-49. 1, 2, 4, 5, 8, sample Sa-04-09; 3, sample Sa-04-08; 6, 7, sample Sa-04-06.

Fig. 9. Scolopodus striatus Pander. S element GIT 495-50. Sample Sa-04-12.

Figs 10, 11. Oepikodus evae Lindström. 10, M element GIT 495-51; 11, P element GIT 495-52. Sample Sa-04-14.

Fig. 12. Jumudontus gananda Cooper. GIT 495-53. Sample Sa-04-14.

Fig. 13. Oistodus lanceolatus Pander. GIT 495-54. Sample Sa-04-12.

Figs 14, 15, 17-21. Tripodus sp. GIT 495-55 to GIT 495-61. 14, 15, sample Sa-04-09; 17-21, sample Sa-04-12.

Fig. 16. Oelandodus? costatus van Wamel. GIT 495-63. Sample Sa-04-09.

Figs 1, 4, 6, 10, 15, $17 \times 90$; figs $2,3,7,11,12,16,19 \times 120$; figs $5,14 \times 80$; figs $8,13,18,22 \times 60$; figs $9,21 \times 50$

All conodonts from the Saka section. 


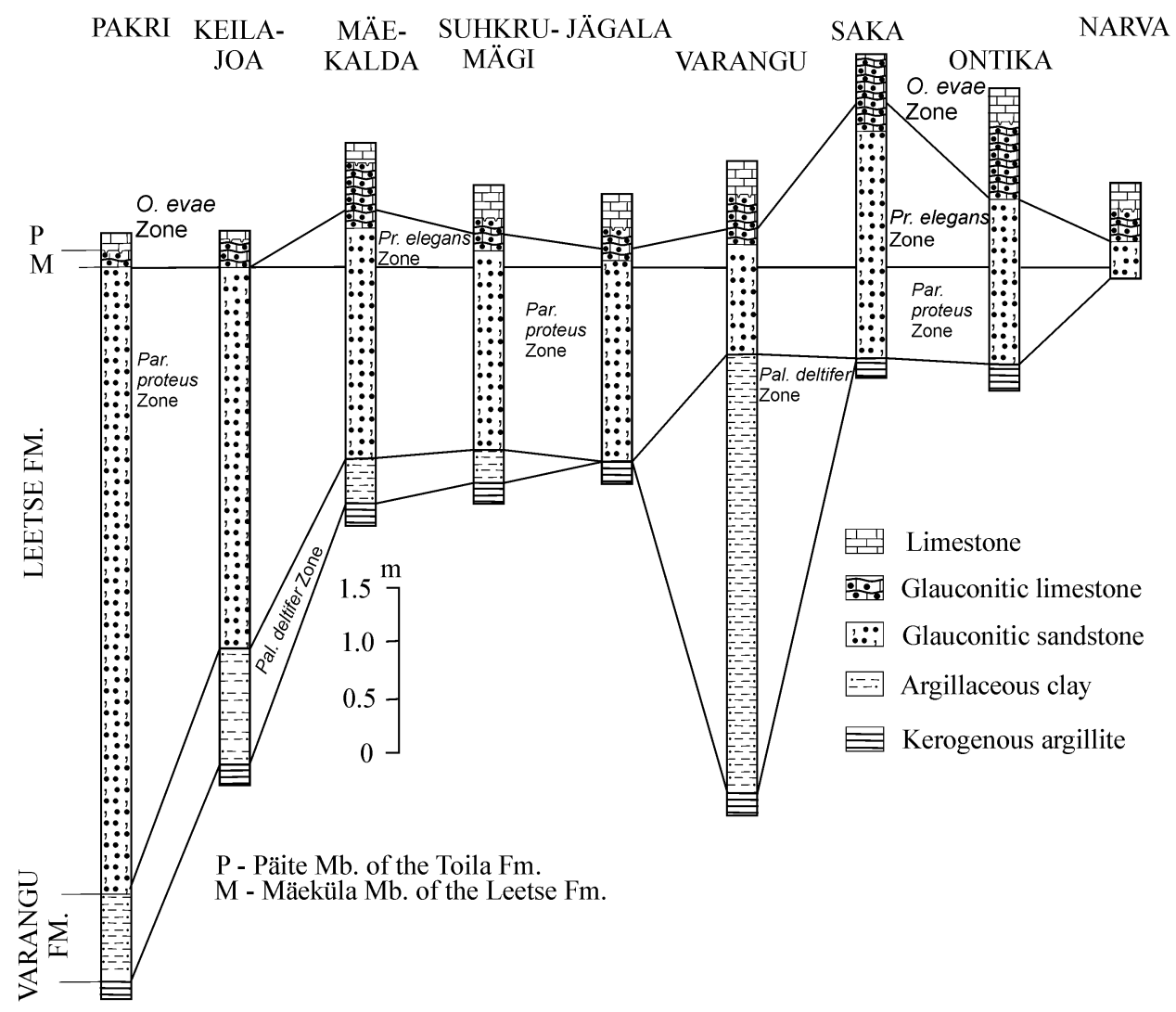

Fig. 3. Biostratigraphical correlation of selected sections on the North Estonian Klint. The sections are redrawn in general outline from the following sources: Pakri Cape (Löfgren et al. 2005); KeilaJoa and Varangu (Mägi \& Viira 1976; Mägi et al. 1989); Mäekalda (Viira et al. 2001); Suhkrumägi (Viira 1966); Varangu (Viira et al. 1970); Ontika (Mägi 1984). Conodonts from Jägala and Narva are unpublished, selected specimens are illustrated in Viira (1974).

been identified by "old" names. In Sweden D. forceps and Paltodus subaequalis first appear in this subzone. The latter species occurs quite early in Estonian sections, indicating the Tripodus Subzone. The third, Paracordylodus gracilis Subzone was established by a single specimen only in the Saka section, for the first time in Estonia. Löfgren (1994) has chosen this species to mark the lower boundary of the subzone, because it is a particularly widespread taxon and thus has great correlation potential. Paracordylodus gracilis has been found from pelagic to neritic shallow-water facies, except for extremely shallow water facies (Tolmacheva \& Löfgren 2000). In Sweden, the uppermost, Oelandodus elongatusAcodus deltatus Subzone has been determined by the appearance of the first and a frequency maximum of the second index species. In Estonia, the upper subzone is represented mainly by $A$. deltatus, while Oelandodus elongatus is rare. 


\section{GRAIN-SIZE DISTRIBUTION}

A total of 37 samples from the Leetse Formation of the Pakri Cape and Saka sections were analysed for grain-size data. In the present discussion only siliciclastic and glauconite particles are considered (Fig. 4) without other authigenic minerals and bioclasts to understand better the mode of terrigenous matter influx into the basin. The relative proportion of saltative $(>0.05 \mathrm{~mm})$ and suspended $(<0.05 \mathrm{~mm})$ fractions is shown in the same figure to illustrate the continuity of the hydrodynamic regime and rate of sedimentation.

Based on the grain-size data, both of the studied sections can be subdivided into three lithologically different parts. Among them, the lowermost part is particularly distinct.

The lowermost part (samples Pa-96-1 to Pa-96-7 and Sa-04-01 to Sa-04-05B; Fig. 4) is represented by unsorted sandstones with minor thin intervals of argillaceous sediments. Glauconite content as well as the number of saltative particles in clastic material are variable. These factors suggest that this poorly sorted interval has accumulated comparatively rapidly in high-energy hydrodynamic conditions. However, judging by the occurrence of coarse-grained particles, it might be concluded that such a situation was complicated by temporal currents.

The succeeding middle part (Pa-96-8 to Pa-96-15 and $\mathrm{Sa}-04-06$ to $\mathrm{Sa}-04-10)$ is lithologically homogeneous and represented mainly by fine- and very fine-grained sandstones. The content of glauconite grains and suspended particles varies within very small limits. These phenomena, together with the absence of even mediumsized sand grains, indicate quiet-water environment of sedimentation and a low rate of siliciclastic material influx into the sedimentation basin.

The uppermost part of the formation (Pa-96-15 to Pa-96-20 and Sa-04-10 to Sa-04-15) is represented by sand-, silt-, and claystones alternating with carbonate lenses and interlayers. It is gradually passing upwards into the glauconitic limestones of the Toila Formation, characterized by the start of extensive carbonate accumulation. Both the glauconite content and the ratio of saltative to suspended fraction are quite variable in the grain-size distribution of that part of the succession.

The heterogeneous character of the uppermost part of the succession marks not only the changes in the hydrodynamic conditions inside the palaeobasin, but mostly changes in climatic conditions, influenced by the drift of Baltica palaeocontinent into the subtropical climatic zone. This idea coincides nicely with the palaeomagnetic data (Scotese 1997).

Thus, although the entire Pr. elegans Zone is missing in the Pakri Cape section, the grain-size distribution of sediments in both studied sections is similar: poorly sorted deposits of basal beds of the Par. proteus Zone are followed by the homogeneous sandy-clayey part and terminated by the appearance of the first carbonate sediments on the top, roughly corresponding to the $O$. evae Zone.

Lateral comparison of the studied sections shows some essential differences. The Leetse Formation in the Pakri Cape section is about twofold thicker than in the Saka section and only a minor amount of suspended fraction is present in the 


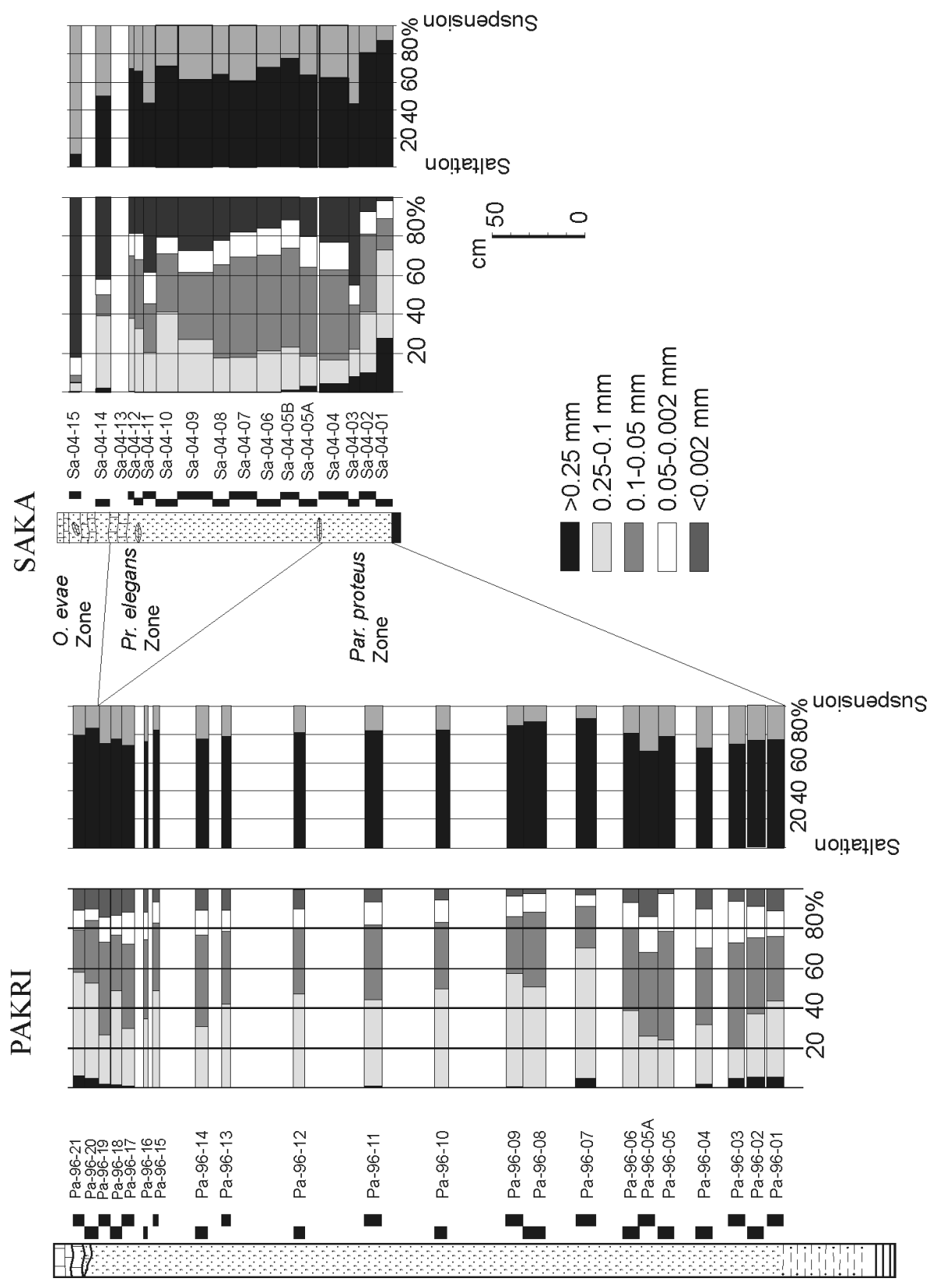

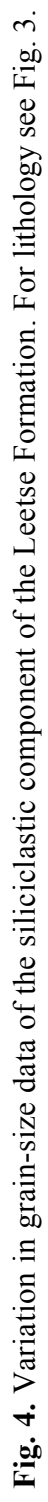


western part of the basin. This indicates repeated redeposition of sediments, as a result of which the finely dispersed material was winnowed out. Such a conclusion is also supported by a great number of redeposited conodont elements in the deposits of the Leetse Formation in the Pakri Cape section (Löfgren et al. 2005).

Regardless of the small thickness of the Leetse Formation in the Saka section, its sequence is biostratigraphically the most complete on the North Estonian Klint. In contrast to the Pakri Cape section, the clay fraction content in the glauconite sandstones of the Saka section is much higher. These phenomena indicate a slow continuous shallow-water sedimentation accompanied by low input of terrigenous material into that part of the Leetse palaeobasin.

\section{GLAUCONITE MINERALOGY}

Glauconite mineralogy and chemical composition carry relevant information on the speed of sedimentation and burial rate of these grains (Odin 1988; Amorosi 1997). The SEM-EDX studies show that the distribution of elements, such as $\mathrm{Mg}, \mathrm{K}, \mathrm{Fe}, \mathrm{Si}, \mathrm{Al}$, and $\mathrm{O}$, inside glauconite grains is comparatively homogeneous (Fig. 5). Thus, each grain may represent an individual glauconite formation act, which is in equilibrium with its exposure time on the sediment/water surface.

On the other hand, frequency analyses of the chemical composition of glauconite grains (samples Pa-96-01 and Sa-04-04; Fig. 6) revealed obvious overall asymmetry in element content distribution. Judging by the distribution of aluminium, iron, and potassium, glauconite in the studied samples is represented by two discrete modifications. Logically, the diagenetic alteration of glauconite grains should change their chemical composition monotonously. Most likely, this phenomenon might be attributed to the ratio of in situ buried to redeposited (i.e. repeatedly affected by synsedimentary development) glauconite grains, similarly to conodont redeposition evident from the Pakri Cape section (Löfgren et al. 2005).
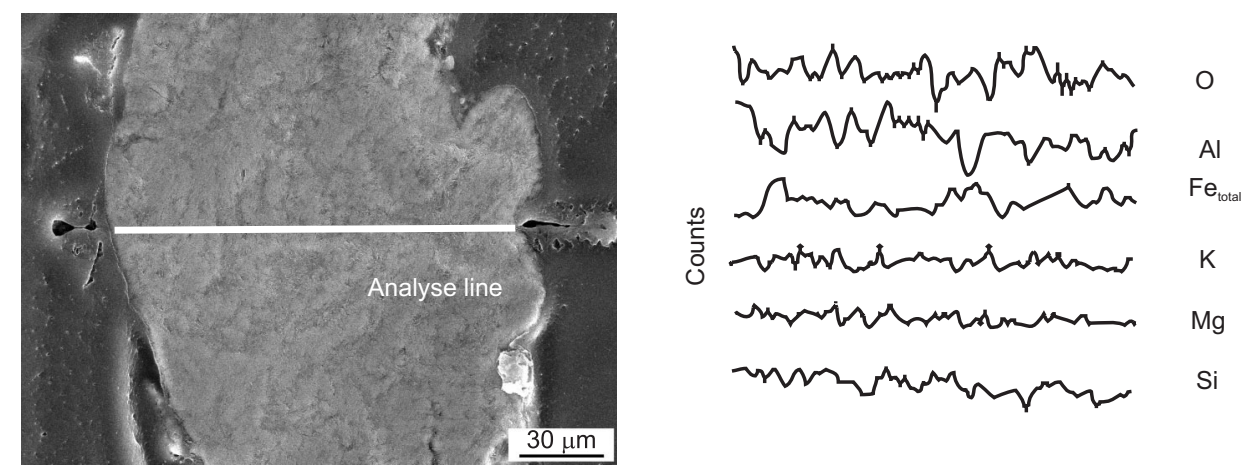

Fig. 5. Typical EDX-WDX analyse lines over a glauconite grain. Pakri Cape section, sample Pa-96-01. 

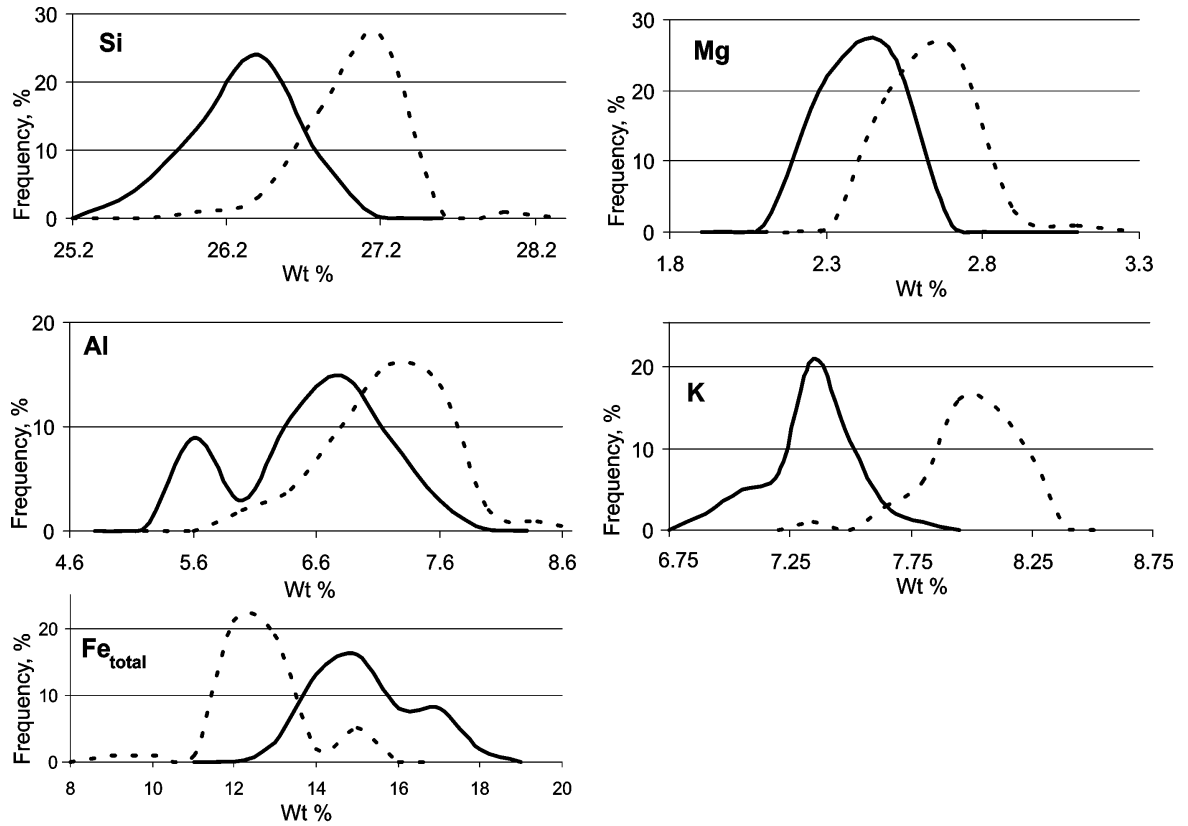

Fig. 6. Frequency distribution of basic elements of glauconite in the Pakri Cape (sample Pa-96-01, solid line) and Saka (sample Sa-04-04, dotted line) sections. Curves are constructed on the basis of measurements of 50 individual grains from both samples.

The overall chemical composition of glauconite displays systematic differences between western and eastern regions. On average, the chemical composition of glauconite of the Leetse Formation in the western Pakri Cape section is as follows (wt \%): $\mathrm{MgO}, 3.8 ; \mathrm{K}_{2} \mathrm{O}, 8.8 ; \mathrm{Al}_{2} \mathrm{O}_{3}, 12.0 ; \mathrm{Fe}_{2} \mathrm{O}_{3}, 19.6$ (total iron content was calculated as being in that oxydation level), and $\mathrm{SiO}_{2}, 55.8$. In the eastern Saka section these values were different: $\mathrm{MgO}, 7.0 ; \mathrm{K}_{2} \mathrm{O}, 9.54 ; \mathrm{Al}_{2} \mathrm{O}_{3}, 13.23 ; \mathrm{Fe}_{2} \mathrm{O}_{3}$, 17.40, and $\mathrm{SiO}_{2}, 57.50 \mathrm{wt} \%$. These values generally coincide with earlier published ones (Nikolajeva 1977), reflecting, however, certain differences in the character of sediment accumulation in the Leetse basin. A lower average content of potassium in the glauconite from the western part of the study area might be interpreted as an indicator of faster sediment accumulation (in comparison with the eastern part). However, judging by conodont data (Löfgren et al. 2005 and this study), mostly the lowermost conodont zones characteristic of Leetse time are represented in the Pakri Cape section. Consequently, due to hydrodynamic regime, sediment accumulation in the western part of the Leetse basin was intermittent, while in the eastern part (Saka section), this process was significantly more continuous.

However, element content distributions (Fig. 6) suggest that the chemical composition of glauconite should be studied in individual grains. In that case similarities and even coincidences between some fractions become evident. 
The upper limit of $\mathrm{K}_{2} \mathrm{O}$ content for mineral glauconite is defined as $9 \%$ (Velde 2003). Substitution of potassium into a glauconite interlayer is in strict correlation with exposure time on sediment surface (Amorosi 1997).

On the other hand, the potassium content is rigidly attributed to the position of 001 reflection (Odin 1988). Consequently, $d$-spacing of the 001 XRD reflection, affected almost exclusively by the $\mathrm{K}$ content in glauconite, can be used as an indicator of the average sedimentation speed. The values of measured 001 reflections for the Pakri Cape and Saka sections are shown in Fig. 7.

Vertical changes in measured $d$-spacings were similar in the western and eastern parts of the studied area. However, the values of glauconite 001 reflection positions were lower in the eastern part than in the western part, while the measured average content of potassium, on the contrary, was higher (compare Figs 6 and 7). It is assumed here that the sedimentary history of $0.1-0.25 \mathrm{~mm}$ glauconite grains is more complicated than that of the $0.05-0.1 \mathrm{~mm}$ fraction. Most likely, the finer glauconite fraction, which was subjected to XRD analyses, reflects syngenetic

PAKRI
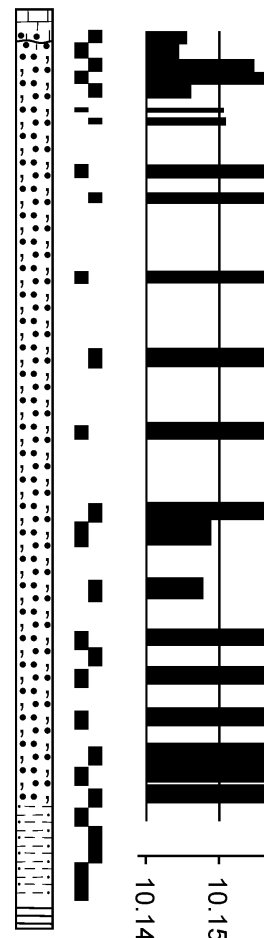
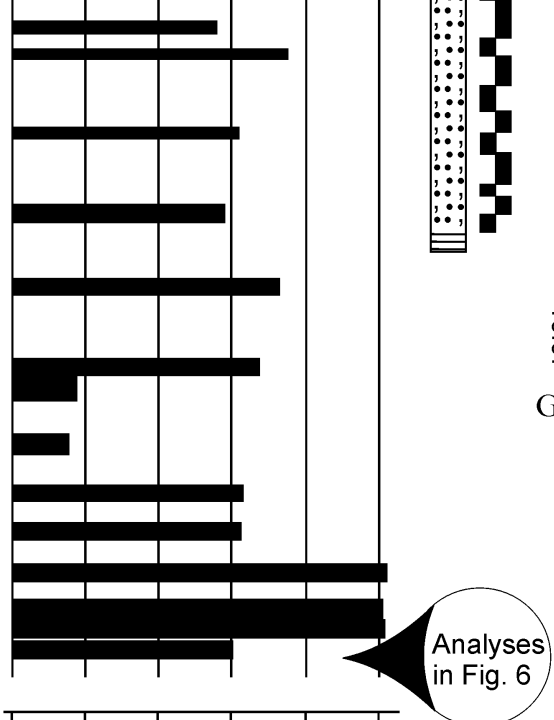

$\begin{array}{llllll}\overrightarrow{0} & \overrightarrow{0} & \overrightarrow{0} & \overrightarrow{0} & \overrightarrow{0} & \overrightarrow{0} \\ \vec{A} & \overrightarrow{\vec{v}} & \vec{\sigma} & \stackrel{\vec{V}}{\overrightarrow{0}} & \overrightarrow{\vec{v}}\end{array}$

Glauconite $\mathrm{d}_{(001)}, \AA$
SAKA
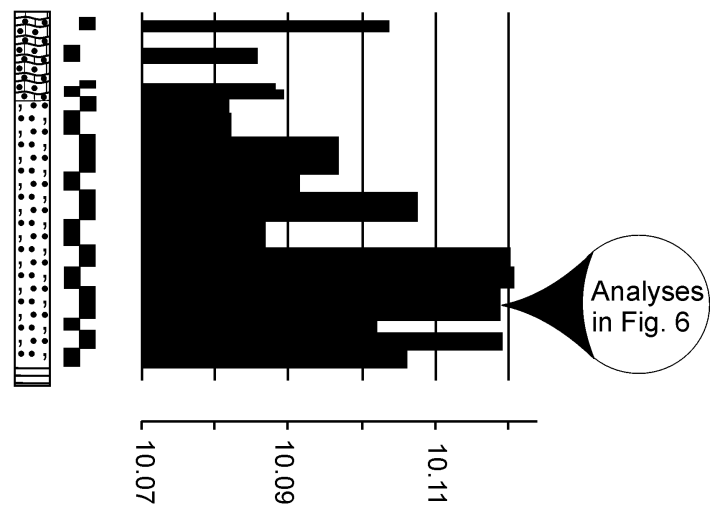

Glauconite $\mathrm{d}_{(001)}, \AA$

Fig. 7. Values of glauconite $d_{(001)}$ values in the Pakri Cape and Saka sections. For lithology see Fig. 3. 
conditions while the coarser one represents rather a redeposition history. However, from systematic differences in $d$-spacings it can be concluded that the influx of siliciclastic sediments was low, but more continuous in the eastern part of the studied area (particularly in the Saka section), while in the western part sedimentation was more irregular.

\section{CONCLUSIONS}

The glauconitic sandstones of the Leetse Formation correspond to the Paroistodus proteus, Prioniodus elegans, and Oepikodus evae conodont zones. In the westernmost section (Pakri Cape), the Leetse Formation is represented by the Par. proteus and O. evae zones, while in the eastern part (Saka section) all three conodont zones are present, with the majority of the sequence belonging to the Pr. elegans Zone. The redeposition, reworking, and mixing rate of conodont elements differs significantly along the klint area, being largest in the western part. Differences in conodont assemblages suggest that in the eastern part of the studied area sedimentation in the shallow-water palaeobasin was more quiet and persistent than in the western part.

Similar to conodont zonation, grain-size distribution shows that the sediments of the Leetse Formation in the western part have deposited under high hydrodynamic regime. Due to such conditions, conodont elements and saltative particles (including glauconite grains) were repeatedly redeposited and most of the suspended material was washed out.

In the east, the homogeneous structure of the Leetse Formation (at least in its middle part) and presence of well-sorted sandstones, as well as abundant occurrence of suspended matter, unanimously refer to slow, continuous shallowwater sedimentation. This conclusion is also supported by the lack of redeposited conodont elements in this part of the basin.

Frequency distribution analyses of aluminium, iron, and potassium of glauconite grains showed (at least, in two studied samples) that they were represented by at least two discrete modifications. The glauconite of the Leetse Formation in the eastern part of the studied area contains more K and more Fe. Vertically, $d_{(001)}$ values of glauconite in the Leetse Formation succession tend to decrease, indicating acceleration of sedimentation. The lowest values have been recorded in the Mäeküla Member. However, more detailed study of XRD properties and chemistry of glauconites is necessary in order to find out relations between their grain size and the sedimentation feature they represent.

The grain-size data and changes in XRD properties of glauconite, correlated on the basis of conodont biozonation, were found to be in good accordance during Hunneberg and Billingen time. However, the lateral differences in the Leetse basin were found to be significant. 


\section{ACKNOWLEDGEMENTS}

The authors express their gratitude to D. Kaljo for helpful notes and discussions. Gennadi Baranov is acknowledged for assistance in preparation of the plates. This study is a contribution to IGCP Project 503 and was supported by the Estonian Science Foundation (grant No. 5922). The reviewers A. Löfgren and E. Pirrus are thanked for their constructive remarks and corrections.

\section{REFERENCES}

Amorosi, A. 1997. Detecting compositional, spatial, and temporal attributes of glaucony: a tool for provenance research. Sedim. Geol., 109, 135-153.

Bergström, S. M. 1988. On Pander's Ordovician conodonts: distribution and significance of the Prioniodus elegans fauna in Baltoscandia. Senckenbergiana Lethaea, 69, 217-251.

Kleesment, A. \& Mägi, S. 1975. On the lithology and mineralogy of terrigenous glauconite deposits in Ceratopygian and Latorpian stages of Estonian structural-facial zones. Eesti NSV Tead. Akad. Toim. Keemia Geol., 24, 55-63 (in Russian).

Löfgren, A. 1993. Conodonts from the lower Ordovician at Hunneberg, south-central Sweden. Geol. Mag., 130, 215-232.

Löfgren, A. 1994. Arenig (Lower Ordovician) conodonts and biozonation in the eastern Siljan District, central Sweden. J. Paleontol., 68, 1350-1368.

Löfgren, A., Viira, V. \& Mens, K. 2005. Conodont biostratigraphy and sedimentary history in the upper Tremadoc at Uuga, Pakri Cape, NW Estonia. GFF, 127, 283-293.

Mägi, S. 1970. The Ontikan rocks in Central and West Estonia. Eesti NSV Tead. Akad. Toim. Keemia Geol., 19, 141-146 (in Russian).

Mägi, S. 1984. A characterization of the type section of the Ontika subseries. Proc. Acad. Sci. Estonian SSR Geol., 33, 104-112 (in Russian).

Mägi, S. \& Viira, V. 1976. On distribution of conodonts and inarticulate brachiopods in Ceratopyge and Latorpian stages. Eesti NSV Tead. Akad. Toim. Keemia Geol., 25, 312-318 (in Russian).

Mägi, S., Viira, V. \& Aru, H. 1989. On the correlation of the Tremadocian and Arenigian boundary beds in the East Baltic. Proc. Acad. Sci. Estonian SSR Geol., 38, 63-67.

Meidla, T. 1997. Hunneberg Stage. Billingen Stage. In Geology and Mineral Resources of Estonia (Raukas, A. \& Teedumäe, A., eds), pp. 58-61. Estonian Academy Publishers, Tallinn.

Nikolajeva, I. V. 1977. Minerals of Glauconite Series in Sedimentary Systems. Nauka, Novosibirsk.

Odin, G. S. (ed.) 1988. Green Marine Clays. Elsevier, Amsterdam.

Öpik, A. 1936. Konodontidest. Eesti Loodus, 3, 105-107.

Pander, C. H. 1856. Monographie der fossilen Fische der Silurischen Systems der russisch-baltischen Gouvernements. St. Petersburg Acad. Wissenschaften, 1-91.

Scotese, C. R. 1997. Paleogeographic Atlas, PALEOMAP Progress Report 90-0497. Department of Geology, University of Texas at Arlington, Arlington, Texas.

Tolmacheva, T. Ju. 2001. Conodont Biostratigraphy and Diversity in the Lower-Middle Ordovician of Eastern Baltoscandia (St. Petersburg Region, Russia) and Kazakhstan. Comprehensive summary of doctoral dissertation, Uppsala University, Uppsala.

Tolmacheva, T. \& Löfgren, A. 2000. Morphology and paleogeography of the Ordovician conodont Paracordylodus gracilis Lindström, 1955: comparison of two populations. J. Paleontol., 74, 1114-1121.

Tolmacheva, T. Ju., Koren, T. N., Holmer, L. E., Popov, L. E. \& Raevskaya, E. 2001. The Hunneberg Stage (Ordovician) in the area east of St. Petersburg, north-western Russia. Paläontol. Z., 74, 543-561. 
Velde, B. 2003. Green clay minerals. Treatise Geochem., 7, 289-308.

Viira, V. 1966. Distribution of conodonts in the Lower Ordovician sequence of Suhkrumägi (Tallinn). Eesti NSV Tead. Akad. Toim. Füüs.-Mat. Tehn.-tead. Seeria, 15, 151-155 (in Russian).

Viira, V. 1970. Conodonts of the Varangu Member (Estonian Upper Tremadoc). Eesti NSV Tead. Akad. Toim. Keemia Geol., 19, 224-233 (in Russian).

Viira, V. 1974. Ordovician Conodonts of East Baltic. Valgus, Tallinn (in Russian).

Viira, V., Kivimägi, E. \& Loog, A. 1970. On the lithology and age of the Varangu Member (Tremadocian, North-Estonia). Eesti NSV Tead. Akad. Toim. Keemia Geol., 19, 147-155 (in Russian).

Viira, V., Löfgren, A., Mägi, S. \& Wickström, J. 2001. An Early to Middle Ordovician succession of conodont faunas at Mäekalda, northern Estonia. Geol. Mag., 138, 699-718.

\section{Alam-Ordoviitsiumi Leetse kihistu Põhja-Eesti panga läbilõikes}

\section{Viive Viira, Kaisa Mens ja Jüri Nemliher}

Leetse kihistu koosneb valdavalt glaukoniidirikastest liivakividest, milles esinevad üksikud savi- ja karbonaatkivimi vahekihid ning läätsed.

Tuginedes konodontide leviku biotsonaalsusele, on võrreldud kombineeritult selleaegsete setendite lõimist ning glaukoniidi mineraloogiat Pakri ja Saka läbilõigetes. Eesmärgiks on iseloomustada Leetse ajal valitsenud settimistingimusi ja nende muutlikkust. Konodontide levikupilti on täiendatud klindialale jääva seitsme läbilõike andmetega.

Konodontide leviku alusel vastavad Leetse kihistu setendid kolmele biotsoonile (alt üles): Paroistodus proteus, Prioniodus elegans ja Oepikodus evae. Nende tsoonide osatähtsus üksikutes läbilõigetes on varieeruv.

Kihistu paksus, osaliselt ka setendite lõimis, sõltub suurel määral settebasseinis valitsenud hüdrodünaamikast ja purdmaterjali sissekande hulgast ning kiirusest. Pakri läbilõikes on kihistu paksus määratud põhiliselt mitmekordselt ümbersetitatud purdmaterjali akumuleerumisega, mille käigus on peenemad fraktsioonid välja uhutud. Korduvat ümbersetitamist ja samuti kiiret mattumist kinnitab ka ümbersettinud konodontide elementide kõrge sisaldus setendites ning madalam kaaliumi sisaldus glaukoniidis, võrreldes analoogiliste näitajatega Saka läbilõikes.

Eestisse jääva Leetse paleobasseini idaosa iseloomustab pidevam, väga aeglane settimine, mis toimus suhteliselt madalaveelises keskkonnas. Selle tagajärjel moodustunud glaukoniitliivakivi lasum Saka läbilõikes on biostratigraafiliselt täielik, väga madala ümbersettinud konodondielementide esinemisega ja kõrge kaaliumisisaldusega glaukoniidis. 